\title{
Transcatheter aortic valve-in-valve insertion: That train has sailed
}

\author{
Kevin L. Greason, MD
}

From the Department of Cardiovascular Surgery, Mayo Clinic, Rochester, Minn

Disclosures: Author has nothing to disclose with regard to commercial support.

Received for publication Oct 11, 2016; accepted for publication Oct 11, 2016; available ahead of print Nov 8, 2016.

Address for reprints: Kevin L. Greason, MD, Department of Cardiovascular Surgery, Mayo Clinic, Rochester, MN 55905 (E-mail: greason.kevin@ mayo.edu).

J Thorac Cardiovasc Surg 2017;153:264-5

$0022-5223 / \$ 36.00$

Copyright (c) 2016 by The American Association for Thoracic Surgery

http://dx.doi.org/10.1016/j.jtcvs.2016.10.032

\section{"That train has sailed.”}

$$
\text { -Austin Powers }
$$

I congratulate Stock and colleagues ${ }^{1}$ on their efforts to bring some science to the issue of transcatheter aortic valvein-valve insertion. Members of the multidisciplinary transcatheter heart team will recognize that the technique of transcatheter aortic valve-in-valve insertion did not transition from the benchtop to the operating room, but with the present publication appears to be rightly moving backward from the operating room to the benchtop. Readers of the Journal will find interest in this article because it addresses the paucity of translational research in the area of transcatheter aortic valve-in-valve surgery.

Transcatheter aortic valve-in-valve insertion seems to be an ideal procedure at first glance. It avoids the pitfalls of repeat sternotomy, cardiopulmonary bypass, and aortic crossclamp-induced myocardial ischemia. Data published from the Global Valve-in-Valve Registry are not as encouraging as expected, however, with $25 \%$ of patients noted to have a mean systolic transvalvular gradient of $20 \mathrm{~mm} \mathrm{Hg}$ or more, additional valve-in-valve insertion needed in $8.4 \%$ of patients, and a combined rate of death or major stroke noted in $10.4 \%$ of patients. ${ }^{2}$ These are not good results. Of specific importance to this commentary is that ostial coronary obstruction was reported in $3.5 \%$ of patients. Despite the concerning outcomes, the government expanded the use of transcatheter aortic valve insertion to aortic "valve-in-valve" replacement in $2015^{3,4}$

I performed a PubMed search of the English language for "transcatheter aortic valve-in-valve" insertion and identified 304 articles. My review identified that the first proof of concept for transcatheter aortic valve-in-valve insertion was in a porcine model reported by Walther and colleagues 5 in July 2007, which was soon followed by a successful clinical case reported by Wenaweser and colleagues ${ }^{6}$ in November 2007. But as far as I can determine, the first in vitro case study of transcatheter aortic valve-in-valve insertion reported was by Midha and colleagues ${ }^{7}$ in

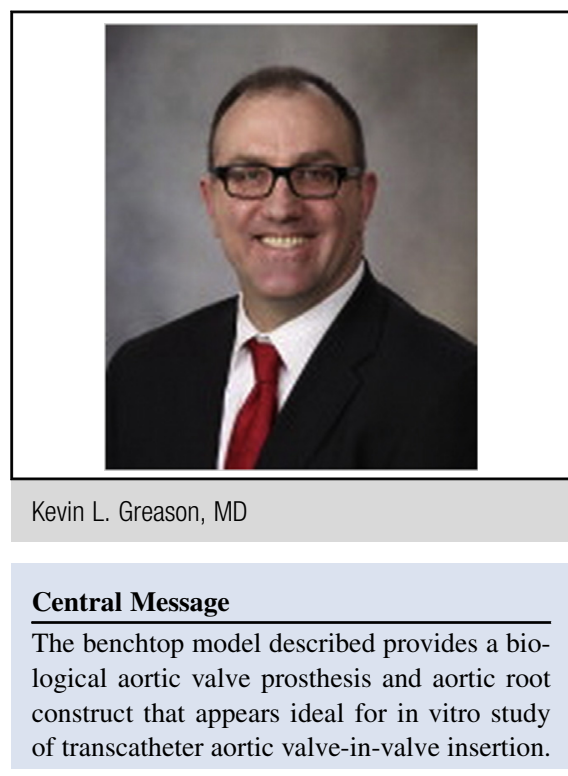

See Article page 255.
December 2015, which occurred after the Food and Drug Administration approval of the procedure. Of the remaining 301 articles, $299(99.3 \%)$ reported only on clinical aspects of valve insertion. The present study is a welcome addition to the basic sciences understanding of transcatheter aortic valve-in-valve insertion.

In this study, Stock and colleagues ${ }^{1}$ present their work with a laboratory model of transcatheter aortic valve-invalve insertion using the SAPIEN XT (Edwards Lifesciences Corp, Irvine, Calif) transcatheter prosthesis in a stented aortic valve prosthesis. The authors sought to study coronary artery obstruction and geometric orifice area after transcatheter aortic valve-in-valve insertion in stented valves with internally mounted cusps (ie, Edwards Perimount Magna valve; Edwards Lifesciences Corp) and externally mounted cusps (ie, St Jude Trifecta; St Jude Medical, Saint Paul, Minn). Stock and colleagues ${ }^{1}$ reported no significant differences in the coronary blood flow or geometric orifice area after transcatheter aortic valve-in-valve insertion in the respective calcified stented prostheses.

The strength of the study is that Stock and colleagues have developed a benchtop model of a biological aortic valve prosthesis and aortic root construct that is capable of producing physiologic coronary artery flow. The model 
appears to be a foundation on which additional investigations can be built. However, the methodology may have contained a fundamental error in that the 2 distances studied from the aortic valve annulus to coronary artery ostia were $8 \mathrm{~mm}$ and $10 \mathrm{~mm}$, and these distances may have been too long. In their treatise on coronary obstruction in transcatheter aortic valve-in-valve insertion, Dvir and colleagues ${ }^{8}$ reported that risk is based on much shorter distances: less than $3 \mathrm{~mm}$, high risk; 3 to $6 \mathrm{~mm}$, intermediate risk; and greater than $6 \mathrm{~mm}$, low risk. A type II statistical error could be present.

The present study is a great start, but additional evaluation is indicated to further understand the impact on hemodynamic outcome of other transcatheter valve types and sizes, other stented biological valve types and sizes, and specific transcatheter valve deployment positions in relation to the stented prosthesis. The transcatheter aortic valve-invalve train has sailed. With less than enthusiastic clinical results, however, it is time to go back to the laboratory to better understand the problem. The benchtop model described offers an experimental basis with which to begin investigation.

\section{References}

1. Stock S, Scharfschwerdt M, Meyer-Saraei R, Richardt D, Charitos EI, Sievers HH et al. In vitro coronary flow after transcatheter aortic valve-in-valve implantation: a comparison of two valves. J Thorac Cardiovasc Surg. 2017;153:255-63.e1.

2. Dvir D, Webb J, Brecker S, Bleiziffer S, Hildick-Smith D, Colombo A, et al Transcatheter aortic valve replacement for degenerative bioprosthetic surgical valves: results from the global valve-in-valve registry. Circulation. 2012;126: 2335-44.

3. FDA News. FDA expands use of CoreValve system for aortic "valve-in-valve" replacement. Available at: http://www.fda.gov/NewsEvents/Newsroom/Press Announcements/ucm440535.htm. Accessed October 9, 2016

4. FDA News. Edwards Lifesciences wins FDA approval for aortic valve-in-valve procedures. Available at: http://www.fdanews.com/articles/173640-edwardslifesciences-wins-fda-approval-for-aortic-valve-in-valve-procedures. Accessed October 9, 2016.

5. Walther T, Falk V, Dewey T, Kempfert J, Emrich F, Pfannmuller B, et al. Valve-invalve concept for transcatheter minimally invasive repeat xenograft implantation. J Am Coll Cardiol. 2007:50:56-60.

6. Wenaweser P, Buellesfeld L, Gerckens U, Grube E. Percutaneous aortic valve replacement for severe aortic regurgitation in degenerated bioprosthesis: the first valve in valve procedure using the Corevalve revalving system. Catheter Cardiovasc Interv. 2007;70:760-4.

7. Midha PA, Raghav V, Condado JF, Arjunon S, Uceda DE, Lerakis S, et al. How can we help a patient with a small failing bioprosthesis? An in vitro case study. $J \mathrm{Am}$ Coll Cardiol Intv. 2015:8:2026-33.

8. Dvir D, Leipsic J, Blanke P, Riberior HB, Konowski R, Pichard A, et al. Coronary obstruction in transcatheter aortic valve-in-valve implantation: preprocedural evaluation, device selection, protection, and treatment. Circ Cardiovasc Interv. 2015;8(1). pii: e002079. 